\title{
Oral hygiene in patients using removable dentures
}

\begin{abstract}
Introduction. Properly designed and used denture is conducive to proper rehabilitation of edentulism.

Aim. The aim of the study was to assess the knowledge and hygiene habits of patients using removable partial dentures (RPDs) including selected sociodemographic characteristics.

Material and methods. The survey comprised 321 individuals wearing RPDs, the residents of the Lublin Province. They were asked about the age, gender, place of residence, education, duration of denture usage, repairs made to RPDs, preparations used for cleansing and disinfection of RPDs, storage at night, causes of visiting the dentist, which was associated with the use of the RPD and the frequency of visits. The results were statistically analyzed.

Results. The average duration of removable partial dentures use was $7.8 \pm 5.7$ years. The vast majority of respondents cleaned RPDs with a toothpaste $-90.9 \%$, almost $2 / 3$ of the surveyed population - did not disinfect their RPDs, $56.4 \%$ people not remove them for the night. Only 3.7\% people visited the dentist on regular basis associated with the use of RPDs.

Conclusions. Among people wearing RPDs, too long duration of current RPD usage is confirmed. Moreover, the dentist does not check them regularly because patients do not visit dentists for check-up. RPDs are cleaned using improper preparations and usually are not disinfected. They are inadequately kept at nighttime, if ever removed from the mouth during sleep. Incorrect handling related to the use of removable partial dentures applies to persons regardless of their level of education and place of residence.
\end{abstract}

Keywords: removable partial dentures (RPDs), sociodemographic characteristics, oral hygiene.

DOI: $10.1515 /$ pjph-2017-0006

\section{INTRODUCTION}

With the increase in life expectancy in Poland, the number of partially or completely edentulous people increases. The basis for prosthetic rehabilitation should be fixed or removable partial dentures (RPDs) fitted on periodontal tissues. In the absence of the abutment teeth, on which denture can be based or when there is no possibility of using residual dentition as the aforementioned abutment teeth, an effective solution is also implant-prosthetic treatment. In Poland, many people for financial reasons decide to dental prosthetic treatment reimbursed by the National Health Fund (NHF), which covers mucosal borne removable acrylic dentures - complete and/or partial.

The dentist, when fitting the removable partial denture, should instruct patients about its proper use, especially when they do it for the first time in their lives. Important information concerns the necessity to take out of the mouth the RPDs for at least 6-8 hours per day and store them in a dry environment [1]. Fitting of RPDs does not mean the final stage of treatment and the patient should remain under the constant control of a dentist. The person wearing the RPD should keep to the designated check-ups, and not just in case of discomfort associated with its use, or sudden events such as fracture/cracking of RPDs [2,3].

Natural teeth of a denture wearer, as well as RPDs require necessary cleaning procedures that allow for maintaining residual teeth and the RPD in good hygienic condition [4]. The results of the survey among denture wearers indicate the existence of problems with maintaining proper hygiene of RPDs [2,5]. This may be related to insufficient knowledge on the subject and manual limitations, which can appear and increase with age in older people. It should be emphasized that even the best-made RPDs during improper use can cause stomatitis and other complications [6].

\section{AIM}

The aim of the study was to assess the knowledge and hygiene habits of patients wearing removable partial dentures including selected sociodemographic characteristics.

\footnotetext{
${ }^{1}$ Department of Prosthodontics Medical University of Lublin, Poland

${ }^{2}$ Department of Mathematics and Medical Biostatistics, Medical University of Lublin, Poland

${ }^{3}$ Chair and Department of Paedodontics, Medical University of Lublin, Poland
} 


\section{MATERIAL AND METHODS}

The survey comprised 321 individuals using RPDs, the residents of the Lublin Province. They were asked about the age, gender, place of residence, education, period of wearing RPDs, repairs made to RPDs, used products for cleaning and disinfection of them, storage of RPDs at night, causes of visiting the dentist, which was associated with the use of RPD and the frequency of visits. The results were statistically analyzed. The values of the analyzed parameters measured in nominal scale were characterized using the frequencies and percentage, while for the assessment of the existence of the relationship between the analyzed characteristics the $\mathrm{Chi}^{2}$ independence test was used. A 5\% inference error and associated significance level $\mathrm{p}<0.05$ were used to indicate statistically significant differences. The database of analyzed data and statistical analyzes were based on computer software Statistica 10.0 (StatSoft, Poland).

\section{RESULTS}

The mean age of the study population was $58.5 \pm 9.7$ years. The study involved 219 women (68.2\%) and 102 men (31.8\%). The average age of women was $59.1 \pm 9.8$ years; the average age of men was $57.4 \pm 9.2$ years. The observed differences were not statistically significant $(\mathrm{t}=1.47 ; \mathrm{df}=319 ; \mathrm{p}=0.14)$. The structure of education was as follows: 70 people $(21.8 \%)$ had primary education, 111 people (34.6\%) - vocational, 119 people $(37 \%)$ - secondary education, 11 people $(3.4 \%)$ - postsecondary, while 2 students $(0.6 \%)$ had bachelor degrees and 8 students $(2.5 \%)$ had higher education degrees. The place of residence for the majority of the respondents was the town with over 200 thousand inhabitants (117 people $-36.4 \%$ ) and the village (107 people $-33.3 \%)$; the town below 50 thousand inhabitants (66 persons $-20.6 \%$ ); the town $50-200$ thousand inhabitants (31 persons - 9.7\%).

The duration of RPDs use ranged from 1 year to 43 years, for half of the patients the duration of use did not exceed 6 years, and the average time of use $-7.8 \pm 5.7$ years.

Throughout the time of use - in 158 respondents $(49.2 \%)$ the RPDs did not require repair, in 110 people (34.3\%) it was necessary to fix the denture after fracture, in 45 people $(14.0 \%)$ there was a need to insert a lost tooth, and 8 people $(2.5 \%)$ did not know anything about the repair of RPD.

The vast majority of respondents cleaned RPDs with a toothpaste -292 persons $(90.9 \%), 12$ patients $(3.7 \%)$ using soap, 3 persons $(0.9 \%)$ - using dishwashing liquid and 14 people $(4.4 \%)$ - other products.

The distribution of responses concerning denture disinfection was as follows: almost $2 / 3$ of the surveyed population -239 persons $(74.5 \%)$ did not disinfect their RPDs, whereas those who disinfected the dentures most commonly used for this purpose: dentrifice -46 persons $(14.3 \%)$ Corega Tabs ${ }^{\circledR}$ tablets -26 people $(8.1 \%)$, hydrogen peroxide -5 people $(1.6 \%)$, baking soda -4 people $(1.2 \%)$ and boiling water 1 person $(0.3 \%)$.

The answers to the frequency of disinfection of used RPDs show that 41 people (12.8\%) did it once a week, 21 people $(6.5 \%)$ - once every two weeks, others did it occasionally -20 people $(6.2 \%)$. Special preparations for RPDs and mucous membranes were used by 225 respondents $(70.0 \%)$. The most commonly mentioned preparations were: denture creams and adhesives -22 persons $(6.9 \%)$, denture cleansing tablets -91 subjects $(28.3 \%)$, gels and ointments for irritated gums and mucous membranes - 39 persons $(12.1 \%)$, denture cleaning brushes $-71(22.1 \%)$, other preparations (without providing details) -2 persons $(0.6 \%)$.

The question: "How do you store your RPD at nighttime?" was answered in the following ways: "I do not remove it for the night" -181 persons (56.4\%), "I keep RPD in a container with water or liquid" -87 people (27.1\%), "I store it in a dry container" -53 people (16.5\%).

It was found that persons with primary and vocational education significantly more often reported wearing of RPDs for 24 hours $(61.7 \%$ vs. $50.0 \%)$, while respondents having completed at least secondary education significantly more often stored the RPD in a dry container $(22.9 \%$ vs. $11.7 \%)$. The observed differences were statistically significant $\left(\mathrm{Chi}^{2}=7.81, \mathrm{df}=2, \mathrm{p}=0.02\right)$ (Table 1).

Table I. Handling of a RPDs at night taking into account the level of education.

\begin{tabular}{lcccc}
\hline \hline \multicolumn{1}{c}{$\begin{array}{c}\text { Level of } \\
\text { education }\end{array}$} & $\begin{array}{c}\text { I do not } \\
\text { remove it at } \\
\text { nighttime }\end{array}$ & $\begin{array}{c}\text { I store it } \\
\text { in a container } \\
\text { with liquid }\end{array}$ & $\begin{array}{c}\text { I store it } \\
\text { in a dry } \\
\text { container }\end{array}$ & Total \\
\hline $\begin{array}{l}\text { Primary } \\
\text { and vocational } \\
\text { education }\end{array}$ & 111 & 48 & 22 & 181 \\
\cline { 2 - 5 } & $61.67 \%$ & $26.67 \%$ & $11.67 \%$ & $100 \%$ \\
\hline $\begin{array}{l}\text { Secondary, } \\
\text { licentiate, } \\
\text { and higher }\end{array}$ & 70 & 38 & 32 & 140 \\
\hline eductaion & $50.00 \%$ & $27.14 \%$ & $22.86 \%$ & $100 \%$ \\
\hline Total & 181 & 87 & 53 & 321 \\
\hline
\end{tabular}

Although there were no statistically significant differences in the behavior of rural and urban residents, however, it was observed that almost two-fold higher percentage of the urban population removes their RPDs at nighttime and stores them in a dry container $(19.6 \%$ vs. $10.3 \%)\left(\mathrm{Chi}^{2}=5.29 \mathrm{df}=2 ; \mathrm{p}=0.062\right)($ Table 2$)$.

Table 2. Handling of a RPDs at night taking into account the place of residence.

\begin{tabular}{lcccc}
\hline \hline $\begin{array}{c}\text { Place of } \\
\text { residence }\end{array}$ & $\begin{array}{c}\text { I do not } \\
\text { remove it at } \\
\text { nighttime }\end{array}$ & $\begin{array}{c}\text { I store it } \\
\text { in a container } \\
\text { with liquid }\end{array}$ & $\begin{array}{c}\text { I store it } \\
\text { in a dry } \\
\text { container }\end{array}$ & Total \\
\hline Village & 68 & 28 & 11 & 107 \\
\hline Town* & $63.55 \%$ & $26.17 \%$ & $10.28 \%$ & \\
\hline \multirow{2}{*}{ Total } & 113 & 59 & 42 & 214 \\
& $52.80 \%$ & $27.57 \%$ & $19.63 \%$ & \\
\hline
\end{tabular}

*Town (this category includes all the patients living in towns with over 200,000 inhabitants, 50,000-200,000 inhabitants, and below 50,000 inhabitants).

The most common reason of visiting the dentist were the problems associated with the RPD usage - 176 persons $(54.8 \%)$, while in the case of 12 patients $(3.7 \%)$, there were regular visits. The remaining respondents -133 people $(41.5 \%)$ did not visit the dentist in connection with the RPD usage. The presented behaviors were statistically significant, different for women and men $\left(\mathrm{Chi}^{2}=6.29 ; \mathrm{df}=2 ; \mathrm{p}=0.04\right)$. The percentage of men visiting the dentist because of a problem with the RPD was significantly higher ( $64.7 \%$ vs. $50.2 \%)$, and significantly more women were visiting the dentist for a check-up visit in connection with the RPD usage ( $4.6 \%$ vs. $2.0 \%$ ) (Table 3 ). 
Table 3. Reason of visiting the dentist into account of gender.

\begin{tabular}{lccc}
\hline \hline \multicolumn{1}{c}{ Reason of visiting the dentist } & Women & Men & Total \\
\hline \multirow{2}{*}{ Problem associated with the RPD usage } & 110 & 66 & \multirow{2}{*}{176} \\
\cline { 2 - 3 } & $50.23 \%$ & $64.71 \%$ & \\
\cline { 1 - 3 } Control visit & 10 & 2 & \multirow{2}{*}{12} \\
\cline { 2 - 3 } & $4.57 \%$ & $1.96 \%$ & \\
\hline \multirow{2}{*}{ Not visit dentist } & 99 & 34 & \multirow{2}{*}{133} \\
\cline { 2 - 3 } & $45.20 \%$ & $33.33 \%$ & \\
\hline \multirow{2}{*}{ Total } & 219 & 102 & 321 \\
& $68.2 \%$ & $31.8 \%$ & $100 \%$ \\
\hline
\end{tabular}

There was no difference in visiting the dentist between the village and urban dwellers $\left(\mathrm{Chi}^{2}=4.46 ; \mathrm{df}=2 ; \mathrm{p}=0.102\right)$. There was a similar proportion of patients who did not report on the visits (46.7\% - the town; $49.6 \%$ - the village). In addition, the proportion of patients who visited the dentist due to problems with the RPDs use was comparable in both groups (37.4\% of those living in the towns, $38.2 \%$ in rural areas).

\section{DISCUSSION}

One of the important elements to ensure proper rehabilitation of edentulism with removable partial dentures is their appropriate use by the patient, i.e. correct cleaning, storing, regular visits to the dentist, as well as appropriately frequent replacement of the RPDs. Poor oral hygiene, also with regard to RPDs, and the accumulation of plaque, contribute to inflammation of the mouth, gingivitis, periodontitis, dental stomatitis and oral malodour. There is a correlation between the incidence of yeast-like fungus and clinical indicators reflecting unsatisfactory oral condition and intensified inflammatory processes [7]. Microbiological studies show that patients with residual dentition using partial or complete dentures have more pathogenic microorganisms than those without dentures [8]. Increased bacterial-fungal colonization, especially the presence of opportunistic microorganisms on the dentures and in the oral cavity, with hygienic neglect, may adversely affect overall health [9]. It should be added that too long use of the same removable denture is not conducive to proper prosthetic rehabilitation.

According to the results of the review conducted by MacEntee, the RPDs should not be used for more than 5 years, since after that time they may have harmful effects on the oral tissues [10]. In our study, the average time of RPD use was 7.8 years, longer than it should result from clinical practice. It does not diverge from the findings in other studies, which show that over 6 years of use of the RPDs is confirmed by $65 \%$ of patients [11] or that a percentage of $24.53 \%$ to more than $50 \%$ of Brazilian population has used the RPDs for more than 20 years [2,12]. In Polish conditions, it is possible to make some of RPDs every five years as part of the National Health Fund benefits.

In our research study, only $3.7 \%$ of patients using RPDs regularly visited the dentist every six months for a control examination. At the check-up visit, not only RPDs can be corrected, but oral examination is carried out - assessment of hygiene conditions, or of periodontological preventive and therapeutic needs, conservative and surgical treatment, etc. Correction of occlusion disorders prevents RPD damage and fracture and overloads of own teeth in the case of partial removable dentures [13]. The fact that few patients after receiving RPDs visit the dentist again is confirmed by Marchini et al., who in their research state that only $23 \%$ of patients visit the dentist again within 10 years of RPD use [3].

Many studies confirm the fact that dentists do not give advice on proper care of dentures [4,14-18]. The patient should clean his/her denture every day with little abrasive cleaning agents, and once a year the denture should be subjected to a professional cleaning by a dentist or dental hygienist using ultrasonic methods [14]. It has also been shown that additional use at home of cleansing effervescent tablets is conducive to better hygiene of the RPD [19-21]. In our study, 90.9\% of the patients reported using abrasive toothpaste to clean the RPDs, which was found to be a common phenomenon $[11,22]$. It is known that the use of toothpaste results in an increase in the roughness of the surface of the acrylic base plate, which promotes the adhesion of the bacterial plaque to the denture surface [23]. It is noted that the acrylic denture plate creates favorable conditions for the accumulation of bacterial plaque - because of the porosity of the acrylic, the higher temperature under the denture plate due to the poor thermal conductivity of the acrylic; and additional mechanical damage to the plate favors plaque buildup. An impaired flow of saliva is also an important factor, and therefore difficult self-cleaning of the mouth [8].

RPD disinfection is an important hygienic treatment, and preparations containing sodium hypochlorite are considered the most effective, as confirmed by in vitro studies [24]. A high proportion of patients in our study ( $2 / 3$ of the total) did not disinfect their RPDs, which confirms the low level of knowledge about proper use of the dentures.

Non-removing of the RPD during nighttime can contribute to inflammation of the mucous membrane due to the accumulation of bacterial plaque $[3,25]$. On the other hand, not keeping the RPD in a dry environment but in a container with liquid promotes the growth of microorganisms on the surface of the dentures. Improper handling of the RPDs at nighttime has been shown in many surveys around the world [4,26-30]. Correct handling of the dentures was showed in our study by only $16.5 \%$ of people - they remove their RPDs at nighttime and store them in a dry place.

\section{CONCLUSIONS}

Among people using RPDs, too long time of wearing them is confirmed and that is not routinely controlled by the dentist because patients fail to come on follow-up visits. RPDs are cleansed with inadequate agents and are not usually disinfected. They are also inadequately stored at nighttime if they are taken out of the mouth at all during sleep. Improper handling of RPDs concerns people regardless of their level of education and place of residence, while greater attention to regular check-up visits is confirmed among women.

\section{REFERENCES}

1. Zissis A, Yannikakis S, Harrison A. Comparison of denture stomatitis prevalence in 2 population groups. Int J Prosthodont. 2006;19(6):621-5.

2. Peracini A, Andrade IM, Paranhos Hole F, et al. Behaviors and hygiene habits of complete denture wearers. Braz Dent J. 2010;21(3):247-52.

3. Marchini L, Tamashiro E, Nascimento DFF, Cunha VPP. Self-reported denture hygiene of a sample of edentulous attendees at a University dental clinic and the relationship to the condition of the oral tissues. Gerodontol. 2004;21(4):226-8 
4. Dikbas I, Koksal T, Calikkocaoglu S. Investigation of the cleanliness of dentures in a university hospital. Int J Prosthodont. 2006;19(3):294-8.

5. Kulak-Ozkan Y, Kazazoglu E, Arikan A. Oral hygiene habits, denture cleanliness, presence of yeasts and stomatitis in elderly people. J Oral Rehabil. 2002;29(3):300-4

6. Naik AV, Pai RC. A study of factors contributing to denture stomatitis in a north Indian community. Int J Dent. 2011;2011:589064. [http://dx.doi. org/10.1155/2011/589064. PMid:22194746.]

7. Perkowski K, Zawadzki PJ, Starościak B, et al. Składniki mikrobiomu jamy ustnej jako czynnika ryzyka zakażeń lokalnych i uogólnionych u pacjentów bez oraz z wadami rozwojowymi narządu żucia. Post Mikrobiol. 2016;55(1):57-67.

8. Jermakow K, Sokalska J, Więckiewicz W, Gościniak G. Zmiany składu mikroflory jamy ustnej u pacjentów z uzębieniem resztkowym rehabilitowanych protetycznie. Forum Zakażeń. 2012;3(1):7-12.

9. Przybyłowska D, Mierzwińska-Nastalska E. Wpływ higieny jamy ustnej i uzupełnień protetycznych na zdrowie ogólne. Nowa Stomatol. 2013;2:83-

10. MacEntee MI. The prevalence of edentulism and diseases related to dentures - a literature review. J Oral Rehabil. 1985;12(3):195-207.

11. Cakan U, Yuzbasioglu E, Kurt H, et al. Assessment of hygiene habits and attitudes among removable partial denture wearers in a university hospital. Niger J Clin Pract. 2015;18(4):511-15.

12. Coelho CMP, Sousa YTCS, Daré AMZ. Denture-related oral mucosal lesions in a Brazilian school of dentistry. J Oral Rehabil. 2004;31(2):135-9.

13. McCord JF, Grant AA. Prosthetics: Trial dentures, insertion of processed dentures and review of complete dentures. Br Dent J. 2000;189(1):4-8.

14. Mierzwińska-Nastalska E. Zasady użytkowania, czyszczenia i pielegnacji protez całkowitych. Protet Stomatol. 2011;61(4):293-303.

15. Salerno C, Pascale M, Contaldo M, et al. Candida-associated denture stomatitis. Med Oral Patol Oral Cir Bucal. 2011;e139-43.

16. Ribeiro DG, Pavarina AC, Giampaolo ET, et al. Effect of oral hygiene education and motivation on removable partial denture wearers: longitudinal study. Gerodontol. 2009;26(2):150-6.

17. Sadig W. The denture hygiene, denture stomatitis and role of dental hygienist. Int J Dent Hyg. 2009 Aug [cited 2015 Mar 23]; Available from: http://doi.wiley.com/10.1111/j.1601-5037.2009.00413.x.
18. Lee H-E, Li C-Y, Chang H-W, et al. Effects of different denture cleaning methods to remove Candida albicans from acrylic resin denture based material. J Dent Sci. 2011;6(4):216-20.

19. Dills SS, Olshan AM, Goldner S, Brogdon C. Comparison of the antimicrobial capability of an abrasive paste and chemical-soak denture cleaners. J Prosthet Dent. 1988;60(4):467-70.

20. Cruz PC, Andrade IM de, Peracini A, et al. The effectiveness of chemical denture cleansers and ultrasonic device in biofilm removal from complete dentures. J Appl Oral Sci Rev FOB. 011;19(6):668-73.

21. Oliveira LV, Mesquita MF, Henriques GEP, et al. The compatibility of denture cleansers and resilient liners. J Appl Oral Sci. 2006;14(4):286-90.

22. Ercalik-Yalcinkaya S, Özcan M. Association between oral mucosal lesions and hygiene habits in a population of removable prosthesis wearers. J Prosthodont. 2015;24(4):271-8

23. Izumida FE, Jorge JH, Ribeiro RC, et al. Surface roughness and Candida albicans biofilm formation on a reline resin after long-term chemical disinfection and toothbrushing. J Prosthet Dent. 2014;112(6):1523-9.

24. Lee D, Howlett J, Pratten J, et al. Susceptibility of MRSA biofilms to denture-cleansing agents. FEMS Microbiol Lett. 2009;291(2):241-6.

25. Hoad-Reddick G, Grant AA, Griffiths CS. Investigation into the cleanliness of dentures in an elderly population. J Prosthet Dent. 1990;64(1):4852.

26. Mierzwińska-Nastalska E, Rusiniak K, Gontek R, Okoński P. Wpływ higieny uzupełnień protetycznych na powstawanie infekcji grzybiczej błony śluzowej. Nowa Stomatol. 2000;4:52-5.

27. Frączak B, Stawska B. Potrzeby protetyczne pensjonariuszy Domów Pomocy Społecznej. Protet Stomatol. 2006;56(4):305-11.

28. de Castellucci Barbosa L, Ferreira MRM, de Carvalho Calabrich CF, et al Edentulous patients' knowledge of dental hygiene and care of prostheses. Gerodontol. 2008;25(2):99-106.

29. Baran I, Nalçacı R. Self-reported denture hygiene habits and oral tissue conditions of complete denture wearers. Arch Gerontol Geriatr 2009;49(2):237-41.

30. Veres EM, Wolfaardt JF, Hnizdo E. Denture cleansers: Part I - A survey of the availability of denture cleansers in South Africa. J Dent Assoc South Afr Tydskr Van Tandheelkd Ver Van Suid-Afr. 1985;40(10):581-3.

\section{Corresponding author}

Jolanta Szymańska

Chair and Department of Paedodontics,

Medical University of Lublin

7 Karmelicka St., 20-081 Lublin, Poland

E-mail: szymanska.lublin@gmail.com 